\title{
Acute haemolytic anaemia due to IgM penicillin antibody in a 3-year-old child: A sequel to oral penicillin
}

\author{
G. W. G. BIRD, M. W. McEVOY 1 , AND JUNE WINGHAM
}

From the West Midlands Regional Blood Transfusion Service, Birmingham, and the Guest Hospital, Dudley, Worcestershire

SYNOPSIS A hitherto undescribed form of immune haemolytic anaemia due to penicillin antibody is described. The antibody, which was of the IgM class, fixed complement and caused acute haemolysis. Oral penicillin seems to have been responsible both for antibody production and, on subsequent exposure, for the haemolytic anaemia.

Since the first description of penicillin antibody (Ley, Harris, Brinkley, Liles, Jack, and Cahan, 1958) many examples have been found. The antibody is demonstrable either by direct agglutination of penicillin-coated erythrocytes or by antiglobulin tests. The drug responsible is usually benzylpenicillin but the antibody crossreacts with other penicillins, eg, ampicillin (British Medical Journal, 1968). Cephalosporin antibody also crossreacts with penicillin (references are given by Garraty, 1970).

Although haemolytic anaemia due to penicillin antibody was mentioned by Ley, Cahan, and Mayer (1959), the first detailed report was that of Strumia and Raymond (1962). Several examples have been reported subsequently (White, Brown, Hepner, and Worlledge, 1968).

Worlledge (1973) rightly states that penicillininduced haemolytic anaemia is usually the sequel to large doses of penicillin, and that the antibody responsible is of the IgG class, so that the red cells are destroyed mainly in the spleen, with the gradual development of anaemia.

IgM antibodies to penicillin occur (Fudenberg and German, 1960; Swanson, Chanmougan, and Schwartz, 1966; Rossiter, Gray, and Shinton, 1968), and $\operatorname{IgA}$ and $\mathrm{IgD}$ penicillin antibodies have also been described (Hsu, Rosenfield, Burkart, Wong, and Kochwa, 1974). Antibodies of the IgM, IgA, and IgD classes have not hitherto been implicated as the cause of haemolytic anaemia.

\footnotetext{
'Present address: Harrogate General Hospital, Yorkshire.
}

Received for publication 10 December 1974.

\section{Case Report}

We report here an unusual example of haemolytic anaemia associated with a penicillin antibody.

CLINICAL

M.L., a 3-year-old boy, had no history of previous illness, except for an upper respiratory tract infection at the age of 15 months for which he was given a course of oral ampicillin.

On 1 August 1974 he was admitted to hospital with jaundice and anaemia. Three days before admission he developed a cough for which he had been given $125 \mathrm{mg}$ of penicillin V six hourly for 48 hours. On admission, he was seen to be pale and distressed, with mild icterus. The haemoglobin on admission was $5.4 \mathrm{~g} / \mathrm{dl}$, and a blood film showed polychromasia and spherocytosis. The serum bilirubin level was $3.3 \mathrm{mg} / 100 \mathrm{ml}$, SGOT 66 Frankel units $/ \mathrm{ml}$, and blood urea $57 \mathrm{mg} / 100 \mathrm{ml}$. The Schumm's test for methaemalbumin in plasma was positive. The total white cell count was $29.4 \times 10^{9} / 1$, with neutrophilia and increased numbers of metamyelocytes and stab neutrophils. The platelet count was $260 \times 10^{9} / 1$.

After serological investigation, which is described below, the child was taken off penicillin and put on erythromycin. He was also transfused with 2 units of concentrated red cells. He made an uneventful recovery: the haemoglobin level rose to $13.9 \mathrm{~g} / \mathrm{dl}$ after transfusion and this level was subsequently maintained; the serum bilirubin rapidly returned to normal. 
SEROLOGY

A blood specimen, taken before the patient was transfused, was investigated at the Blood Transfusion Centre. Preliminary investigations showed that the direct Coombs test (broad-spectrum antihuman globulin serum) was strongly positive. There was no evidence of blood group antibody in serum or in eluates from red cells. Whenever there is a strongly positive Coombs test without evidence of blood group antibody, it is our practice to seek evidence of drug involvement other than that of the Aldomet type. Since the only drug administered to the patient was penicillin, tests were carried out on red cells coated with various penicillins as described by Ley et al (1968). The tests showed that the patient's serum contained a strong agglutinin for penicillincoated erythrocytes. This agglutinin was inhibited by prior exposure of the serum to penicillin. The antibody could be eluted and taken up by other penicillin-coated cells which then gave positive direct Coombs tests. The antibody acted strongly at both $37^{\circ}$ and $4^{\circ}$, as did the antibodies described by Bird (1960) and by Rossiter et al (1968).

The patient's erythrocytes were tested with specific antiglobulin sera. It will be seen (table I) that, of the specific antiglobulin sera, only anti-C3 gave a strongly positive and anti-IgM a weaker positive result. It is noteworthy that tests with anti-IgG were negative; this was not the result of 'zoning'. There was no involvement of $\operatorname{IgA}$ or $\operatorname{IgD}$. The agglutinin is therefore a complement-fixing IgM antibody. IgM (or IgG) alloantibodies, which fix complement, often react weakly with anti-IgM (or anti-IgG). This could be due to steric hindrance by complement components of the IgM:anti-IgM reaction. It is also possible that IgM had been partly eluted, leaving complement components adherent to the red cells. Treatment of the patient's serum with mercaptoethanol abolished its activity; this confirms that the antibody belonged to the IgM class. This was further confirmed by inhibition tests using purified immunoglobulins which showed that the antibody was completely inhibited by purified IgM and $C 3$ and not at all by $\operatorname{IgG}, \operatorname{IgA}$, IgD, or IgE.

Penicillin-coated leucocytes and platelets were tested by Mrs L. P. Mackintosh and shown also to

\begin{tabular}{lc}
\hline Antiglobulin Reagent & Test Result \\
\hline Broad-spectrum & +++ \\
Anti-IgG & - \\
Anti-IgM & + \\
Anti-IgA & - \\
Anti-IgD & - \\
Anti-IgE & - \\
Anti-C3 & +++ \\
\hline
\end{tabular}

Table I Results of tests with various antiglobulin sera react with the patient's serum. Untreated platelets did not react but untreated leucocytes were strongly agglutinated.

\section{Discussion}

Penicillin-induced haemolytic anaemia caused by IgG antibodies has been described by Dawson and Segal (1961), by Lai, Rosner, and Ritz (1966) and by White et al (1968). Although several examples of IgM penicillin antibody have been reported, this antibody often accompanied an IgG antibody which caused haemolytic anaemia (Fudenberg and German, 1960, Van Arsdel and Gilliand, 1965; Swanson et al, 1966; Rossiter et al, 1968).

The penicillin-induced haemolytic anaemia of our patient is unusual because it was exclusively due to a complement-fixing IgM antibody which caused acute haemolysis. This contradicts the assertion of Chaplin (1973) that the finding of a 'mixed' or 'complement only' reaction pattern would essentially rule out an immune haemolytic drug reaction caused by penicillin or other agents. The erythrocyte serology of the patient of Rossiter et al (1968), which was carried out by two of us (G.W.G.B. and J.W.), showed that the antibody was a mixture of IgG and IgM. The clinical course, however, suggested the involvement only of IgG. This patient also had leucopenia and thrombocytopenia.

Although penicillin-coated leucocytes and platelets were agglutinated by our patient's serum, there was no evidence of leucopenia or thrombocytopenia. Leucocytosis induced by the respiratory infection may have compensated. We have as yet no explanation for the agglutination of normal leucocytes by the patient's serum.

Bird (1960) doubted if a haemagglutinating antibody to penicillin, subsequently identified as IgM (Bird, 1961), was a true immune antibody, because of its apparently equal activity at $37^{\circ}$ and $4^{\circ}$. However, it seems from the work of Fellner, Klaus, Baer, and Rausen (1971) that both IgG and IgM penicillin antibodies are of immune origin.

Oral penicillin was apparently responsible both for the production of penicillin antibody and, after subsequent exposure, for the haemolytic anaemia in our patient. The stimulus for antibody production could have been exposure to fungi of the Penicillum species as suggested by Howard Hughes (1955) in connexion with penicillin sensitivity.

There was no other obvious cause of acute haemolytic anaemia, so that it is virtually certain that penicillin antibody was responsible. It was considered unethical subsequently to give the child penicillin to see if acute haemolytic anaemia would again develop. 
The chemical basis of penicillin antigenicity has been extensively investigated. Under mild conditions, benzylpenicillin in aqueous solution rearranges to benzylpenicillinic acid. Penicillinic acid reacts with proteins to form conjugates which are potent antigens (De Weck and Eisen, 1960). Other derivatives of the penicillin molecule may also be antigenic (Levine, 1960; De Weck and Eisen, 1960; Josephson, 1960). Indeed Levine (1960) thought that penicillamine might be responsible for the antigenic properties of penicillin. Josephson (1960), however, found that penicillamine did not inhibit penicillin-induced haemagglutination. In view of the fact that penicillamine is used in the treatment of various disorders, eg, Wilson's disease, rheumatoid arthritis, it might be useful to reinvestigate the possible role of penicillamine in the production of positive direct Coombs tests, and perhaps haemolytic anaemia.

According to Chisholm, English, and MacLean (1966), it is 6-aminopenicillanic acid, a metabolic derivative of penicillin, which combines irreversibly with protein to form an antigenic determinant. This structure is present in ampicillin which our patient had at the age of 15 months and in penicillin $V$ which produced the haemolytic anaemia. Ampicillin (Penbritin) is a semisynthetic derivative of 6aminopenicillanic acid. The subject has been critically reviewed by Watson (1962).

The mechanism whereby penicillin antibody is produced seems not to have been clearly elucidated but the major haptenic determinant is thought to be the benzylpenicilloyl group (Garraty, 1962).

We do not know of any other example of the involvement of oral penicillin in the production of immune haemolytic anaemia except that of Rossiter et al (1968). In their case, slight anaemia followed both the intramuscular administration of penicillin in 1961 and oral administration in 1966. It is of interest in this connexion, therefore, that an immune haemolytic anaemia induced by oral tetracycline hydrochloride has been reported by Wenz, Klein, and Lalezari (1974).

We are indebted to $\mathrm{Dr}$ C. Leyland, consultant paediatrician, for permission to report this case.

\section{References}

Bird, G. W. G. (1960). Penicillin antibody. J. clin. Path., 13, 51-53.
Bird, G. W. G. (1961). Unpublished observation.

British Medical Journal (1968). Annotation: Penicillin-induced haemolytic anaemia. 3, 4.

Chaplin, H., Jr. (1973). Clinical usefulness of specific antiglobulin reagents in autoimmune hemolytic anemias. Progr. Hemat., 8, 25-49 (see p. 45).

Chisholm, D. R., English, A. R., and MacLean, N. A. (1961). Immunologic response of rabbits to 6-aminopenicillanic acid. J. Allergy, 32, 333-342.

Dawson, R. B., Jr., and Segal, B. L. (1966). Penicillin-induced immunohemolytic anemia. Arch. intern. Med., 118, 575-579.

De Weck, A., and Eisen, H. N. (1960). Some immunochemical properties of penicillenic acid: an antigen determinant derived from penicillin. J. exp. Med., 112, 1227-1247.

Fellner, M. J., Klaus, M. V., Baer, R. L., and Rausen, A. R. (1971). Antibody production in normal children receiving penicillin at birth. J. Immunol., 107, 1440-1447.

Fudenberg, H. H., and German, J. L. (1960). Certain physical and biologic characteristics of penicillin antibody. Blood, 15, 683689.

Garraty, G. (1972). Drug-related problems. In A Seminar on Problems Encountered in Pre-Transfusion Tests: 25th Annual Meeting of the American Association of Blood Banks, Washington, D.C., 1972, pp. 33-58. Manual published by the American Association of Blood Banks, Chicago.

Howard Hughes, W. (1955). Penicillin sensitivity. Practitioner, 174, 49-52.

Hsu, T. C. S., Rosenfield, R. E., Burkart, P., Wong, K. Y., and Kochwa, S. (1974). Instrumented PVP-augmented antiglobulin tests. II. Evaluation of acquired hemolytic anemia. Vox Sang. (Basel), 26, 305-325.

Josephson, A. S. (1960). The development of antibodies to penicillin in rabbits. J. exp. Med., 111, 611-620.

Lai, M., Rosner, F., and Ritz, N. D. (1966). Hemolytic anemia due to antibodies to penicillin. J. Amer. med. Ass., 198, 483-484.

Levine, B. B. (1960). Studies on the mechanism of the formation of penicillin antigen. I. Delayed allergic cross-reactions among penicillin $\mathrm{G}$ and its degradation products. J. exp. Med., 112, 1131-1156.

Ley, A. B., Cahan, A., and Mayer, K. (1959). A circulating antibody direct-D (sic) against penicillin. In Proceedings of the 7 th Congress of the International Society of Blood Transfusion, Rome, 1958, edited by L. Hollānder, p. 539. Karger, Basel and New York.

Ley, A. B., Harris, J. P., Brinkley, M., Liles, B., Jack, J. A., and Cahan, A. (1956). Circulating antibody directed against penicillin. Science, 127, 1118-1119.

Rossiter, M. A., Gray, I. R., and Shinton, N. K. (1968). Penicillininduced haemolytic anaemia. Brit. med. J., 3, 616-617.

Strumia, P.V., and Raymond, F. D. (1962). Acquired hemolytic anemia and antipenicillin antibody. Arch. intern. Med., 109, 603-608.

Swanson, M. A., Chanmougan, D., and Schwartz, R. S. (1966). Immunohemolytic anemia due to antipenicillin antibodies: report of a case. New Engl. J. Med., 274, 178-181.

Van Arsdel, P. P., Jr., and Gilliland, B. C. (1965). Anemia secondary to penicillin treatment: studies on two patients with 'nonallergic' serum hemagglutinins. J. Lab. clin. Med., 65, 277-285.

Watson, K. C. (1962). Effect of various penicillin compounds on haemagglutination of penicillin-coated erythrocytes. Immunology, 5, 610-620.

Wenz, B., Klein, R. L., and Lalezari, P. (1974). Tetracycline-induced immune hemolytic anemia. Transfusion, 14, 265-269.

White, J. M., Brown, D. L., Hepner, G. W., and Worlledge, S. M. (1968). Penicillin-induced haemolytic anaemia. Brit. med. J., 3, 26-29.

Worlledge, S. (1973). In Blood Disorders Due to Drugs and Other Agents, edited by R. H. Girdwood, p. 13. Excerpta Medica, Amsterdam. 